\begin{tabular}{|ll|}
\hline $\begin{array}{l}\text { Social Work/Maatskaplike Werk Vol } 57 \text { No 2; Issue 3 } \\
\text { http://socialwork.journals.ac.za/pub }\end{array}$ & doi:http://dx.doi.org/10.15270/52-927 \\
\hline
\end{tabular}

PARENTING A CHILD WHO IS MISUSING ILLEGAL SUBSTANCES: STRENGTHENING FATHERHOOD

Mmathato Matheba, Phuti Kgadima, Keatlegile Mabelane

A qualitative study was undertaken with 13 participants to understand the challenges experienced by fathers who are parenting children misusing illegal substances. The sample was selected through purposive and snowball sampling. Data were gathered through semi-structured interviews and analysed thematically. Principles of credibility, transferability, dependability and confirmability were utilised for data verification. A fatherhood-masculinity model guided this study.

Fathers are often socialised to exercise a particular notion of masculinity, which may limit their engagement with their children. However, findings in this study established that fathers are equally capable of active parenting. Therefore, an awareness of the unique contributions of fathers and supporting them in their role is important.

Keywords: family, fatherhood, illegal substances, masculinity, parenting, substance misuse 


\title{
PARENTING A CHILD WHO IS MISUSING ILLEGAL SUBSTANCES: STRENGTHENING FATHERHOOD
}

\author{
Mmathato Matheba, Phuti Kgadima, Keatlegile Mabelane
}

Ms Mmathato Calphurnia Matheba, Post graduate student, Department of Social Work, UNISA, Pretoria, South Africa.

Dr Phuti Kgadima, School of Social Sciences, Department of Social Work, UNISA, Pretoria, South Africa.

Ms Keatlegile Winne Mabelane, Department of Social Work, UNISA, Pretoria, South Africa.

Keywords: family, fatherhood, illegal substances, masculinity, parenting, substance misuse

\section{INTRODUCTION AND BACKGROUND}

The concept of the misuse of illegal substances refers to the harmful use of psychoactive substances such as alcohol or illegal drugs which may alter a person's lifestyle and behaviour (Baconi, Ciobanu, Vlasceam, Cobani, Negrei \& Bălălău 2015:25). Although much has been researched and disseminated about mothers and their experiences of parenting children who are misusing illegal substances, there is a paucity of research on fathers' experiences (Zanoni, Warburton, Bussey \& McMaugh, 2014:84; Schmitz, 2016:4), the challenges they face and the way that they discharge and manage their parenting responsibilities (Hartley \& Seltzer, 2012:328). Most studies focus on the mothers monitoring their children who are misusing illegal substance and their ability to intercede on behalf of the children (Cadwell, 2011:299). Fathers' involvement in their children's lives is often viewed as optional (Shirani, Henwood, \& Coltart, 2012:27) and secondary (Randles, 2018: 519), and their roles in their children's lives are relegated to the periphery. The result is a scarcity of information on their participation as fathers, while other researchers argue that such neglect is the consequence of traditional notions of fatherhood (Maxwell, Scourfield, Featherstone, Holland, \& Tolman, 2012:162). Historically, fathers' involvement in their children's lives has been restricted to that of breadwinner and disciplinarian (Grundetjern, Copes \& Sandberg, 2019:2; Lasser, Fite \& Wadende, 2011:50). However, the family structures are changing and the experiences of fathers in the $21^{\text {st }}$ century seem to be mutating as well (Stahlschmidt, Threlfall, Seay, Lewis \& Kohl, 2014: 2).

The purpose of this study was to understand the experiences and challenges of fathers parenting children who misuse illegal substances. Fathers play an important role in their children's development (Datchi, 2017:108). For instance, researchers argue that children whose fathers are positively engaged in their lives are more likely to excel socially, emotionally and academically, and they are less likely to engage in substance abuse (Henry, Juilon, Bounds \& Sumo, 2020:20). Therefore, the fathers' conceptualisation and enactment of their experiences and challenges in parenting a child who misuses illegal substances are crucial, because fathers play an important role in the development of the child and the wider family unit and in providing effective support systems for them (Mount \& Dillon, 2014:70). Thus, practitioners, other family members and the wider community could benefit from an awareness of the unique contributions of fathers and their valuable supportive role (Lasser et al., 2011:54).

\section{CONCEPTUAL FRAMEWORK}

There are many demographic characteristics that shape the parent-child relationship; however, researchers contend that the parent's gender is arguably the most examined (Le, Sakaluk, Day \& Impett, 2018:3315). In the light of these observations, the fatherhood-masculinity model was deemed the appropriate conceptual framework to understand how men's performance of their gender impacts on their practices of fatherhood (Enderstein \& Boonzaier, 2015:513).

The fatherhood-masculinity model draws on social constructionist understandings of identity (Enderstein \& Boonzaier, 2015:513). It provides an understanding of how men's definition and performance of their gender identity has an impact on their practices of fatherhood. It further provides a framework to analyse 
the association between fatherhood and masculinity. According to the proponents of this model, fatherhood can be understood in two different ways. First, fatherhood can be understood as a parental status. Second, fatherhood can be understood to refer to fathers' parenting of their biological or social children, conveyed by the term fathering. This study operationalises the understanding of fatherhood as a reference to paternal involvement (Pleck, 2010).

Equally, the term masculinity can also be used in two different ways, namely paternal male gender as a status and as a masculinity orientation. Male gender status refers to a person's being male rather than female. Masculinity orientation, on the other hand, are socially prescribed gender norms and stereotypes that influence the development and persistence of "the traditional masculine role through social cognition and social influence processes" (Datchi, 2017: 46). As Ochsner (2012:92) argues, "being born with male genitals does not make a man a man, neither does it convey anything about his masculinity". The gender roles are influenced by a wide range of factors such as beliefs and cultural norms about the suitability of specific tasks for men or women (Magaraggia, 2012:76).

Consistent with the aim of this study, the fatherhood-masculinity model was able to assist in understanding the traditional notion of masculinity (bravery, emotional disconnectedness, physical connectedness) that participants must deal with in parenting a child who is misusing illegal substances.

\section{RESEARCH METHODOLOGY}

This study adopted a qualitative approach to understand the challenges experienced by fathers regarding their children's substance misusing behaviour. The qualitative approach allowed for the identification and elaboration of the breadth and depth of the participants' subjective experiences (Funk \& Kobayashi, 2014: 1003). Exploratory and descriptive designs were used in this study. An exploratory design was employed since the topic has not been well investigated (Schmitz, 2016:4). The descriptive design was appropriate to provide an accurate account of the participants' lived experiences (Grove, Burns \& Gray, 2013:632).

The research goal of this study was to understand the challenges experienced by fathers regarding their children's illegal substance misusing behaviour. Thus, this study responded to the following central question: What are the challenges experienced by fathers regarding their children's illegal substance misusing behaviour?

Data saturation was reached with 13 Black African fathers who resided in the West Rand, Gauteng province and who were parenting children abusing illegal substances. Purposive and snowball sampling techniques were employed to draw a sample from the population. The participants had to be fathers who were residing in the same household with their biological children who are abusing illegal substances. These fathers had to have knowledge and experience of their children's substance misusing behaviour for at least one year to provide information-rich descriptions of the topic under investigation. In addition, participants needed to be able to express themselves in English, seTswana, seSotho or isiZulu to convey the reality from the perspective of the participants. Fathers whose children were misusing illegal substances but not residing in the same household were excluded. Data were collected through semistructured interviews. The first part of the interview schedule included both the participants' biographical profile (age, marital status and occupation) as well as the biographical information of the children who are abusing illegal substances (age, gender, the drug used). The topics covered in the second segment of the interview schedule included (i) fathers' feelings about their children's illegal substance misuse; (ii) effects of children's misuse of illegal substances on the relationship with their fathers; (iii) effect of the children's misuse of illegal substances on family relationships; and (iv) fathers' struggles to cope with children's illegal substance misusing behaviour. Interviews that were conducted in indigenous) languages other than English were translated by the author 1 and verified by author 2. As Makusha, Richter, Knight, Van Rooyen and Bhana (2013:142) state, "the desired outcome of translation in this study was for meaning rather than literal equivalence". The authors relied on their knowledge and understanding of the participants' indigenous languages to provide a comparable translation and interpretation. 
The data were analysed thematically using Tesch's approach as outlined in Creswell (2014:186). The data analysis process included transcribing and reading the recorded data, followed by thematic analysis until themes were identified and categorised. Credibility of the findings was achieved by triangulation through consulting with various sources knowledgeable about the subject. Confirmability was achieved through documenting in the form of a journal, and recording ideas during data collection and analysis which may have affected the findings, while recommendations from other researchers or individual experts in this field were requested. To ensure dependability, the findings were validated though the use of an independent coder in the data analysis. In this study the element of transferability was enhanced by providing thick descriptions of the findings with appropriate quotations from the participants.

Ethical clearance was provided by the University of South Africa (UNISA), Social Work Departmental Research and Ethics Committee (Ref\#: R\&EC:21/11/17/36653829_16). The following ethical considerations were observed: obtaining written informed consent, assuring confidentiality, protecting participants from harm, and appropriate management of the research data.

\section{PRESENTATION AND DISCUSSION OF FINDINGS Biographical profile of participants}

Table 1 provides the biographical data of the participants.

\section{TABLE 1 \\ BIOGRAPHICAL PROFILE OF THE PARTICIPANTS}

\begin{tabular}{|l|l|l|l|l|l|l|}
\hline \multicolumn{2}{|l}{ Participants' biographical information } & \multicolumn{2}{l|}{$\begin{array}{l}\text { Biographical information of the children who are misusing } \\
\text { illegal substances }\end{array}$} \\
\hline P & Age & Marital status & Occupation & Age & Gender & Drugs used \\
\hline A & 56 & Married & Unemployed & 18 & Male & Nyaope $^{1}$ \\
\hline B & 52 & Married & Unemployed & 27 & Female & Nyaope \\
\hline C & 68 & Married & Pensioner & 18 & Male & Nyaope \\
\hline D & 54 & Married & Unemployed & 26 & Male & Nyaope \\
\hline E & 62 & Married & Pensioner & 26 & Male & Dagga \\
\hline F & 68 & Married & Pensioner & 18 & Male & Nyaope \\
\hline G & 52 & Married & Unemployed & 21 & Male & Nyaope \\
\hline H & 57 & Married & Employed & 27 & Male & Nyaope \\
\hline I & 63 & Married & Pensioner & 25 & Female & Glue \\
\hline J & 47 & Married & Employed & 22 & Male & Crystal Meth/Tik \\
\hline K & 57 & Widow & Employed & $28 \& 30$ & Male \& Female & Nyaope \\
\hline L & 63 & Married & Unemployed & 26 & Male & Nyaope \\
\hline M & 54 & Married & Unemployed & 29 & Male & Dagga \\
\hline
\end{tabular}

Some of the notable observations from the biographical profile are that only three of the 13 participants were employed; the rest were either unemployed or receiving a old age pension grant. Fatherhood is often associated with taking financial responsibilities for the family. The breadwinner narrative defines men's identity, and their success or failure, in terms of their paid work (Schmidt, 2018:447). This refers to the ability to support a family, to be a 'family man', as well as to excel in work that is valued as 'masculine'. Traditionally, a 'family man' is one who has a wife and children, and can provide for his family without assistance (Braun, Vincent \& Ball, 2011:21). Inability to fulfil these masculine roles may lead fathers to suffer from psychological stress (Nelson \& Uecker, 2018:1771). Another observation is that nine of the

1 Nyaope is a mixture of dagga and heroin used increasingly in the Tshwane metropolitan area. There are unconfirmed reports of a concoction of rat poison and anti-retroviral drugs (ARVs) being included in the mixture. However, in all confirmed reports heroin and dagga seem to be the main ingredients (Mokwena, 2016:138).

2 The participant reported on two children who are both abusing drugs. 
13 participants' children were males. This gender disparity is consistent with the widely-held assertion that substance abuse is more prevalent amongst boys than girls (Anderberg \& Dahlberg, 2018:25).

For the purpose of this article the 'child' does not necessarily refer to the age group as specified in the Children's Act 38 of 2005, but rather to the relationship between the participant and the one who is abusing drugs. Contrary to the widely-held assertion that the adolescent stage is a strong predictor of substance abuse (Choate, 2015:462), the participants indicated that most of the children fall within the emerging adulthood stage. This is a developmental phase of the late teens and early twenties (McKinney, Morse \& Pastuszak, 2017: 1207). A possible reason for substance misuse amongst the individuals in emerging adulthood is that their relationships shift from dependence on parents towards greater personal autonomy (Buchanan \& LeMoyne, 2020:263).

The concept of 'parenting' also refers to 'living with' or 'parenting' in the sense of providing for the child, regardless of the child's age. Any person 25 years or older may still be perceived as an adult child by parents (Reczek, Liu \& Umberson, 2010:1205).

Four themes emerged from the data analysis and are presented in Table 2 below.

TABLE 2

\begin{tabular}{|l|l|}
\hline \multicolumn{2}{|c|}{ THEMES } \\
\hline Theme 1 & Fathers' feelings about their children's illegal substance misuse \\
\hline Theme 2 & Effects of children's misuse of illegal substances on the relationship with their fathers \\
\hline Theme 3 & Effects of the children's misuse of illegal substances on family relationships \\
\hline Theme 4 & Fathers' struggles to cope with children's illegal substance misusing behaviour \\
\hline
\end{tabular}

\section{Theme 1: Participants' feelilngs about their children's illegal substance abuse}

One of the key dimensions of the fatherhood-masculinity model is the social constructions of fatherhood that define fathers' relationships with their children (Gregory \& Milner, 2011:589). Compared to the traditional notion of a father who was emotionally disconnected from their children (Bauer \& Giles, 2019:109), the term the new father is used to describe the more nurturing fathers who develop closer emotional relationships with their children (Grundetjern et al., 2019:3; Veteläinen, Grönholm \& Holma, 2013: 2).

Discovering that a child is misusing an illegal substance could trigger various negative emotions and reaction in parents such as anger, helplessness, disappointment, loss, shame, despair, confusion, frustration, worry, embarrassment, stress, sadness, hurt and pity (Schultz \& Alpaslan, 2016:91; Smith \& Estefan, 2014:425). According to Stearns and Parrott (2012:408), it is natural and often difficult to avoid experiencing these emotions after such a discovery. These emotions are often intertwined and difficult to separate.

Some participants expressed their pain and sadness about their child's illegal substance misuse. The following comments illustrate these sorrowful emotions:

My heart is painful when I look at my son. (PH)

It is so painful. I do not know what to do. I tried to talk to him, but it never worked. (PL)

However, the impact varies depending on the sense of responsibility and the gender of the child who is misusing illegal substances in the family, as clarified in the comments below:

It is painful, and it is not nice. More especially to me as his father. I relied on him because he is the only boy amongst the girls. So, it is not nice. When I look at him, I do not think about evil things for him, but rather my heart is so painful. It is not nice. (PD)

I used to love this boy but since he started using drugs, it is a problem. I was so happy. When we had him as he is the only boy; now I regret why I have a boy child. I regret. Even now 
when I see someone giving birth to a baby boy, I feel sorry for them as I do not trust boys any longer. (PL)

In the comments above, it is evident that the parent's disappointment is linked to the child's gender. Goldberg and Carlson (2014:762) report that the quality of a parental relationship is directly connected to their children's behavioural problems. Similarly, Le, Sakaluk, Day and Impett (2018:1) contend that the child's gender may elicit differences in parental expectations and the positions parents expect their children to assume.

The fathers in this study expressed their sorrow when they saw no progress in their children's future, especially academically (Kraljevic, Banozic, Maric, Cosic, Sapunar \& Puljak, 2011:115). Participants expressed their shattered hopes concerning the future of their children in the comments below:

Drugs ruined his future, especially now as I was telling you that I found him jobs several times in the company I am working for and he was always absent from work and I had to talk to the managers until they dismissed him. I realised that these things are destroying his future, even now when I look at him, my heart is sore as I do not know what is going to happen to him when I am gone. (PH)

Sometimes I wake up around 3:00 [am] at dawn thinking about her because if I die what is going to happen about her future and her small child. (PI)

The findings demonstrate the participants' stress and anxieties about the future wellbeing of their children when they (the participants) die. The participants' concerns are genuine because in their study Goldberg and Carlson (2014:763) contend that greater behavioural problems during childhood link to a range of adverse outcomes later in life, including school dropout, greater risk of unemployment after leaving school, drug abuse, mental health problems and criminal behaviour. Ferrey, Hughes, Simkin, Locock, Stewart, Kapur, Gunnell and Hawton (2015:1) confirm that several parents of children who are misusing illegal substances are concerned about the future of their children as they considered their vulnerabilities and expressed concern about their ability to cope as adults.

One participant said that he was willing to sacrifice his own life if such an act could stop his child from illegal substance abuse:

I just do not know what to do. Do you hear me? [asking the researcher] I can sacrifice with death if that means she can stop smoking glue. (PI)

Men who become fathers relate to fatherhood and what it takes to become a good father (Herland, Hauge \& Helgeland, 2015:245). However, a child's misuse of illegal substances may threaten the strongly held beliefs on what it means to be a "good parent" (Smith \& Estefan, 2014:424). Their children's misuse of illegal substances led to some participants questioning their parental capabilities, as the comments below indicate:

I was blaming myself because I think for me not being at home all the time and not being close to him is the cause of his drug usage. I think he could not approach me when he was experiencing challenges. One day he told us that they were abusing him on the streets ... that his friends were abusing and bullying him on the streets. (PG)

I had a painful feeling. A very painful feeling because it caused me stress and I started blaming myself that it is my fault that he ended up using drugs. I asked myself so many questions to which I could not find answers; but I personally blame myself. I am not talking on behalf of any other people. I blame myself. (PC)

One participant who experienced a state of helplessness regarding his child's substance misusing behaviour and viewed this as a punishment from God, had this to say:

I do not know what to do. My life is not good. I feel like God is punishing me through my child, because there is this thing that if we did some evil things, the punishment will go to the 
children. Even today I did not go to church waiting for you. I usually go to church so that they pray for me because they know my child's problems. (PI)

According to Becona, Martínez, Calafat, Juan, Fernandez-Hermida, and Secades-Villa (2012:2), parents associated substance abuse with neglectful parenting, a failure to guide their children properly. This selfblame may result in a reduced sense of self-worth, hopelessness, sadness, depression and contempt for oneself (Zahn, Lythe, Gethin, Green, William, Young \& Moll, 2015: 337).

Misuse of illegal substances can also be a source of embarrassment for the users' parents (Richardson \& Van Brakle, 2011:322). For some participants, their children's misuse of illegal substances brought shame and embarrassment because of their standing in the community.

I do not feel good. It is disturbing. I am a Pastor and when I talk to the congregation I just feel as embarrassed as they quietly say I am preaching the word of God when I cannot discipline my own child. It is disturbing. (PL)

Families of children who misuse illegal substances experience emotions of helplessness, frustration and doubts, contributing to increased anger (Mak, Ho, Thomas, Schooling, McGhee \& Lam, 2010:2). Some participants reported emotions of anger because, despite being well looked after, their children turned to illegal substances.

It creates anger, sometimes I ask myself what I have done wrong to them if they do these things. Because I think of them. I have been behind them since they were small. I looked after them; they never struggled with clothes; they never struggled with anything. If there is any chance that he could leave the home, I will be happy. That is what I can say. (PA)

In some instances this anger and frustration lead to physical abuse, as shown in the comment below:

I keep on saying that the way you are doing it to me, I might do something bad that I do not want to do. But they are pushing me into a corner that may be dangerous to them. Last time I told them that, sometimes we watch on the news that certain men have done something bad to their children and we all get surprised how that could be, but because we do not know how much pressure they put on that particular father; then we think he just do it because maybe he was mad or whatever, but it is because he was forced by the behaviour of the child. (PA)

The participants' narratives corroborate those from previous studies, indicating children displaying problematic behaviour may also trigger destructive parenting strategies and characteristics (Lee, Zhou, Eisenberg \& Wang, 2012:57). One such common strategy is authoritarian parenting, characterised by punishment, harsh discipline and physical restraint (McKinney et al., 2017:1209). This frustration can lead to death, as was the case with a Cape Town (South Africa) mother who was sentenced to a threeyear suspended sentence and community service for killing her addicted son in 2007 after enduring years of mental and physical abuse from him (Samodien, 2018). Furthermore, the father's assertions of their feelings about the children's substance misusing behaviour demonstrates that for them fatherhood entails much more than the 'breadwinner' narrative which drives men to avoid all things deemed feminine or associated with women, including care. On the contrary, fathers in this study proved to be actively involved in their children's lives and displayed genuine concern about their children's future.

\section{Theme 2: Effects of chilren's misuse of illegal substances on the relationship with their fathers}

Being a loving father constitutes an alternative expression of masculinity (Grundetjern et al., 2019:2) or what other authors refer to as positive masculinity (Datchi, 2017: 46; Ratele Shefer \& Clowes, 2012). The key emphasis of this contemporary notion of fatherhood is forming an emotional relationship with the child (Shirani et al., 2012:26) and providing psychological support to children (Veteläinen et al., 2013:2). Some participants reflected the importance of positive parenting, including encouragement of appropriate behaviour (Sheidow, Henry, Tolan \& Strachan, 2014:1356). Despite their children's misuse 
of illegal substances, some participants recognised the importance of maintaining a positive relationship with their children, as the comment below illustrates:

Our relationship has not changed because the child is my happiness and love. If he needs something, he will speak to his mother. The two of them can talk like when he needs money. He does not just come to me because he knows I will ask him what he is doing with the money because there is food in the house. (PF)

The participants' supportive and non-judgmental attitude as espoused in the extracts, emphasised the importance of parental support. According to Tharp and Noonan (2012:516), children are likely to desist from risky behaviour, such as drug abuse, if they sense that the parent is caring and supportive. Beardslee, Datta, Byrd, Meier, Prins, Cerda and Pardini (2018:784) contend that children who established a close emotional bond with their parents are less prone to engaging in substance abuse.

However, illegal substance misuse by children could also lead to an increase with difficulties in parentchild interactions and relationships (Gordo, Oliver-Roig, Martinez-Ampliega, Elejaide, FernandezAlcantara \& Richart-Martinez, 2018:1). Parents, in particular fathers, are likely to be anxious about the relationship breakdown between them and their children (Goldberg \& Carlson, 2014:762). Most participants were explicit about the relationship turning "bad" and reacting with anger. One participant reported feeling "disgust" towards the child:

He disgusts me. I wish he was not staying in the house. (PG)

Similarly, most participants attested to having had a good relationship with their children prior to their misuse of illegal substances. However, they explained that the relationships had since deteriorated because of the children's substance misusing behaviour. The comments below support this conclusion:

The relationship was the best because he is the first-born. Can you believe that from birth I spoiled him with everything, clothes, toys and other stuff? There was no toy that he never had. Clothes were many; I can say he had everything. He flew on an aeroplane from Kagiso [O.R. Tambo International Airport in Gauteng province, South Africa] to Cape Town [Western Cape province, South Africa]. Everywhere I went, I ensured that he went too. That is why I say I blame my disability [the participant has a physical disability] ... he could have been fine, or maybe my disability affected him and he then did things as he pleases. Sometimes I blame myself. (PG)

These comments indicate that the child misuse of illegal substances caused the total breakdown of the previously good relationship. The findings further indicate that, contrary to the widely-held assertion that poor socio-economic status during adolescence is a risk factor for substance misuse (Petruzzi, Pullen, Lange, Parnarouskis, Dominguez, Harris, Quiterio, Lekpeh, Manobah, Henderson \& Borba, 2018:1834), the participants' accounts strongly suggest that there is a weak relationship between the family's economic status and the misuse of illegal substances by children. This is evident in the comment below:

It [the relationship] was good ... too much. He grew up very easy. He got everything that he wanted. He never got short of anything. I never bought myself tracksuits worth R800.00 before, but I started buying a tracksuit of this amount for him. I am doing everything that he needed. I never wore brand new clothes, but he is wearing brand new ... with my money. Do you understand that the relationship was good, between me, him and his mother? There is nothing that can actually make him to do the things that he is doing now. He just left everything, life being good. (PD)

This finding illustrates that the social class of the adolescents has no effect on their patterns of illegal substance use (Skrobanek \& Kuglstatter, 2019:144). A possible explanation for this is that parents' control over children transitioning from childhood to adolescence decreases as children gain greater autonomy and independence (Beardslee et al., 2018:784). As children grow up, they are confronted with new demands in their personal lives. 


\section{Theme 3: Effects of the children's misuse of illegal substances on family relationships}

According to the family system theory, the family is a complex, dynamic and integrated whole, where each member influences and is influenced by other members (Goldberg \& Carlson, 2014: 763). Substance abuse by one family member upsets all aspects of family life (Choate, 2015:461). It influences the family structure and its functioning; it changes how family members fulfil their functions (Smith \& Estefan, 2014:424).

Mothers and fathers are likely to engage in different types of parenting with their children (Smith \& Estefan, 2014:425). Parenthood is traditionally associated with motherhood, whereas men are portrayed through their breadwinning status (Schmitz, 2016:4). According to this gender-based division of labour, mothers often assume the role of primary caretakers (Le, Sakaluk, Day \& Impett, 2019:881). On the other hand, fathers who still identify with conventional (traditional) beliefs of masculinity (Bauer \& \& Giles, 2019:108) are usually portrayed as all-powerful patriarchs wielding enormous power over their families (Lamb, 2010:2). These men are authoritative, controlling, strict and expect to be obeyed unquestionably (Ratele et al., 2012:556; Veteläinen et al., 2013:1). In this context, the parental disagreements on responding to the child abusing drugs are inevitable. A tendency to blame the other partner is common as was evident in the participants' experiences.

Some of the participants' marital relations were strained by the children's illegal substance misuse, as the comments below illustrate:

It nearly broke up our marriage with his mother because there was always tension between me and my wife as she was saying that I am rough on him as I am not the biological father until my wife sees it by herself. (PJ)

It is not alright at all because even his mother is saying I do not love him. So, I then tell her that it is not like I do not like or love him, I only hated his behaviour. I love him, but I cannot be fine with him when he is taking grocery in the house and selling it on the streets, and then I say I love him? Nooo [emphasising]... I cannot do that. (PG)

The findings support the assertion that one family member misusing illegal substances becomes a "disease that disrupts the entire family system" (Smith \& Estefan, 2014:429).

Some participants' responses indicate that the child's addiction influences the whole family order, communication and the participants' relationship with the child who is misusing illegal substances, as reflected in the comments below:

So, when my wife is around I keep quiet like I am not in the house. They can talk, but if you can see that they can really talk is when I can go outside you will hear it in even their voices that they are so happy. So, when I am around it is as if I am checking what they are doing. They have that thing about me. (PF)

In our house, children do as they please. There is no family time, no dinner time where we sit as family at the table and eat and my wife dishes up for us. Anyone who wanted to eat can they go to the pots and dish up for themselves. You see ... something like that. We are a family that does not have rules; it is not right. (PG)

The challenges are that, if he is not at home I do not sleep especially at night. He is not sleeping at home. He will open the doors at night and leave them unlocked. When I realise that he is not home to smoke drugs I have to deal with it. He is rude, not speaking nicely with me. (PJ)

The findings reinforce the observation of Brezina (2010:462) that the misuse of illegal substances by a family member can change how family members relate to one another. According to Schultz and Alpaslan (2016:90), "such changes are often characterised by distorted communication and a lack of understanding among family members." 


\section{Theme 4: Fathers' struggles to cope with children's substance misusing behaviour}

Traditionally, the ability of fathers to provide materially for the children and family was a key indicator of masculinity (Grundetjern et al., 2019:4; Ratele et al., 2012:557). However, some of the fathers face structural impediments such as unemployment that made it difficult to fulfil such a role. Ratele et al. (2012:557) advise that the material context of fatherhood and families need to be kept in mind in analysing and understanding the reported experiences and constructions of fatherhood, especially in many African contexts.

The parents' employment status could influence how parents raise their children (Le et al., 2018:4; Voisin, Kim, Bassett \& Marotta, 2018:09). The coping skills of some participants are constrained by their employment status, as illustrated in the comments below:

I have a big burden on my shoulders, so it is very difficult to cope [sigh]. It is very difficult to cope. I have to go to school every now and then, because they do not cope with studies when they started with drugs... have to cook for them, I have to wash for them the plates; I have to make sure I go and look for food. I am not making money, but I try to get something on the table for them. So, they do not appreciate that. (PA)

The participants' narratives convey the experience of what is termed 'parental stresses' by Gordo et al. (2018:1), which is defined as a set of processes leading to aversive psychological reactions to the demands of parenthood and are experienced as negative feelings toward and about the self and the child (Gordo et al., 2018:1). This parental stress is associated with parents' inability to exercise control over their children's behaviour (Terrett, White \& Spreckley, 2012:18). Unfortunately, children may perceive these constraints as a sign of inadequacy (Voisin et al., 2018:4), thus exerting a negative impact on the parent-child relationships (Cottee \& Roma, 2014:27).

\section{Participants' efforts to acquire professional assistance for their children and their experiences of this}

Most participants sought professional assistance for their children's addictive behaviours, but their efforts were in vain. The relapse phenomenon was attributed to several factors, emphasised in the narrative below:

I took her to a social worker so that she could get help because the social workers know about her addiction; they will know how to deal with this in order to help her maybe by taking her to a rehabilitation centre. The only challenge we have is that the social workers took her to the rehabilitation centre previously, so now we have to start afresh with the rehabilitation centre processes. She was taken to the rehabilitation centre; however, she came back weeks before she had completed the treatment. (PB)

The findings strongly suggest that despite the social workers' efforts to admit individuals who are misusing illegal substances into the rehabilitation institutions, relapse remains the greatest challenge. Individuals who are misusing illegal substances lack motivation for treatment for various reasons. Unfavourable home circumstances may contribute towards a relapse (Appiah, Danquah, Nyarko, OforiAtta \& Aziato, 2017:104). Gender influences individuals' motivation to seek, enter and complete treatment. According to Von Greiff and Skogens (2017:189), males are often motivated by a spouse and friends; females derive the motivation from their parenting responsibilities.

Although the child continued to use drugs, one participant sought assistance from the church:

I took him to church. At church, they told me that they could assist us so that he stops using drugs. However, what I understand is that he has to go to the church, but he only went twice and stopped. He is not consistent in that. He goes when he likes. So, we are struggling with that. (PM)

The extract is consistent with the assertion from Davis (2014:244) that faith-based organisations are increasingly becoming involved in providing services in substance abuse. There are questions regarding 
the function of the church in addressing substance abuse. Reports indicate that faith-based programmes employ diverse approaches to substance abuse, with some churches discouraging individuals from following medical prescriptions when individuals who misuse illegal substance are in their care (Davis, 2014:244). Some participants indicated abstaining from consulting professionals either due to ignorance or because the assistance received was unsatisfactory: The findings strongly suggest that despite the social workers' efforts to admit individuals who are misusing illegal substances into the rehabilitation institutions, relapse remains the greatest challenge. Individuals who are misusing illegal substances lack motivation for treatment for various reasons. Unfavourable home circumstances may contribute towards a relapse (Appiah et al., 2017:104). Gender influences individuals' motivation to seek, enter and complete treatment. According to Von Greiff and Skogens (2017:189), males are often motivated by a spouse and friends; females derive the motivation from their parenting responsibilities.

I never looked for help because I did not know where to go to get help when a child is doing drugs. I heard others saying they went to police station to report and the response was that we beat our children, but when you beat the child they arrest you. I never went anywhere to seek help. (PD)

The participants' narratives are consistent with the assertion by Choate $(2015: 463)$ that the persistent substance abuse by one of its members causes or leads to some families reaching a stage where they disengage and withdraw from the problem.

\section{DISCUSSION}

The goal of this study was to understand the experiences and challenges of fathers who are parenting children who misuse illegal substances. The findings challenge the stereotype of the traditional father as the authoritarian and distant figure (Ratele et al., 2012:4) who is emotionally removed from their children (Bauer \& Giles, 2019:109). Instead the narratives painted a picture of a loving father who expresses positive masculinity (Ratele et al., 2012:4) - performing the "nurturing, caring and protective role" of fathers (Concha, Villar, Tafur-Salgado, Ibanez, \& Azevedo, 2016:171). Although women are still the primary caregivers of children, male participants also value the wellbeing of their children and want them to succeed in life. Therefore, men apparently provide parenting as fully as women do (Rehel, 2014:114). Fathers' contributions are nonetheless complementary to the influences of the mother, and both parents are important in a child's development. Some authors contend that the involvement of fathers in the children's lives is likely to reduce the probability of risky and self-destructive behaviour such as use of illegal substances (Concha et al., 2016: 171; Ratele et al., 2012:555). Thus, practitioners, other family members and the wider community could benefit from an awareness of the unique contributions of fathers and valuing and supporting this role (Lasser et al., 2011:54).

\section{CONCLUSION}

The study amply demonstrated that participants are caring, loving and nurturing fathers who are interested in the welfare of their children who misuse illegal substances. This study contradicts the widely-held assertion that neglectful parenting can be a risk factor for substance use. Most fathers shared (albeit perhaps a subjective perception) that they are caring and involved in their children's lives. Admittedly, the literature is still dominated by a discourse of fatherhood as a good provider who is emotionally distant. This suggests the need for more studies on the emerging role of the father who is caring and willing to give up his own life for the good of his children. Challenging experiences pointed to the issues of weak communication, strained family relationship, and emotional distress. Therefore, this study ultimately recommends a comprehensive multi-component strategy which is family focused to strengthen fatherhood. 


\section{RECOMMENDATIONS}

\section{Recommendation for future and further research}

- The authors contend that the involvement of fathers in their children's lives is likely to reduce the likelihood of risky and self-destructive behaviour such as the use of illegal substances (Concha et al., 2016: 171; Ratele et al., 2012:555). Thus practitioners, other family members and the wider community could benefit from an awareness of the unique contributions of fathers and explicitly valuing this role. Therefore, more studies should be conducted on how the concept of positive masculinity can be incorporated into parenting.

\section{Recommendations for practice}

Fathers of children misusing illegal substances exhibit severe levels of parenting stress. In a study conducted by Fyle-Thorpe (2017:1), fathers were identified as a vulnerable group, experiencing stress, negatively influencing their parenting and risking frustration, especially those with a low income. As indicated elsewhere in this paper, fatherhood is traditionally related to "notions of masculinity and a sense of manliness associated with strength, virility, and dominance" (Concha et al., 2016:171). What is more, society is increasingly demanding fathers to be more actively involved in their parenting role. However, fathers seem not to be adequately prepared for the tasks and responsibilities of fatherhood as related to positive masculinity. Similarly, fathers of children misusing illegal substances report experiencing severe levels of parenting stress, which may require assistance (Torres, Sng \& Deane, 2015:274).

- There is also lack of consensus on fatherhood interventions. It was noted that although there are several programmes for fathers, the literature indicates that the majority of such programmes focus on mothers and their children (Barker, Elles \& Ramchandani, 2017:90; Fagan, \& Iglesias, 1999:244; Henry et al., 2020:20). Admittedly, fatherhood is a complex and multidimensional phenomenon (Yoon, Bellamy, Kim \& Yoon, 2018:497). Therefore, the authors suggest that practitioners establish culturally appropriate fatherhood support groups to explore the role of individual characteristics as well as larger cultural factors as they affect parenting practices, especially for fathers (Concha et al., 2016: 172).

\section{Recommendations for policy}

Barker et al. (2017:90) contend that fathering cannot occur in isolation and therefore this study advocates for a comprehensive multi-component strategy to strengthen fatherhood capacity. For instance, a couplefocused strategy or policy that emphasizes the importance of parents' teamwork, commonly referred to as co-parenting (Zemp, Milek, Cummings, Cinna \& Bodenmann, 2016: 808), would seem appropriate. Such a strategy would be more ideal to engage fathers and their partners. Moreover, it has been established that family interventions focusing on the whole family system could also assist the children who are misusing illegal substances immensely.

\section{REFERENCES}

ANDERBERG, M. \& DAHLBERG, M. 2018. Gender differences among adolescents with substance abuse problems at Maria clinics in Sweden. Nordic Studies on Alcohol and drugs, 35(1): 24-38.

APPIAH, R., DANQUAH, S.A., NYARKO, K., OFORI-ATTA, A.L. \& AZIATO, L. 2017. Precipitants of substance abuse relapse in Ghana: A qualitative exploration. Journal of Drug Issues, 47(1):104-115.

BACONI, D.L., CIOBANU, A., VLĂSCEANU, A.M., COBANI, O.D., NEGREI, C. \& BĂLĂLĂU, C. 2015. Current concepts on drug abuse and dependence. Journal of Mind and Medical Sciences, 2(1):18-33.

BAUER, M.E. \& GILES, A.R., 2019. Exploring single, stay-at-home, and gay fathers' perspectives of masculinity and the influence these have on their understandings of their 4-to 12-year-old children's outdoor risky play. The Journal of Men's Studies, 27(1):108-125. 
BARKER, B., ILES, J.E. \& RAMCHANDANI, P.G., 2017. Fathers, fathering and child psychopathology. Current Opinion in Psychology, 15:87-92.

BEARDSLEE, J., DATTAS, S., BYRD, A., MEIER, M., PRINS, S., CERDA, M. \& PARDINI, D. 2018. An examination of parental and peer influence on substance use and criminal offending during the transition from adolescence to adulthood. Journal of Criminal Justice, 45(6): 783-798.

BECONA, E., MARTINEZ, U., CALAFAT, A., JUAN, M., FERNANDEZ-HERMIDA, J.R. \& SECADES-VILLA, R. 2012. Parental styles and drug use: A review. Journal of Drugs: Education, Prevention and Policy, 19(1)1-35.

BRAUN, A., VINCENT, C., \& BALL, S. J. 2011. Working-class fathers and childcare: The economic and family contexts of fathering in the UK. Community, Work and Family, 14(1):19-37.

BREZINA, T. 2010. Anger, attitudes, and aggressive behaviour: exploring the affective and cognitive foundations of angry aggression. Journal of Contemporary Criminal Justice, 26(2): 186-203.

BUCHANAN, T. \& LEMOYNE, T. 2020. Helicopter parenting and the moderating impact of gender and single-parent family structure on self-efficacy and well-being. The Family Journal, 28(3):262-272.

CADWELL, K. 2011. Systems thinking, organizational change and agency: A practice theory critique of Senge's learning organization. Journal of Change Management, 1-20.

CHOATE, P.W. 2015. Adolescent alcoholism and drug addiction: The experience of parents. Journal of Behavioural Sciences, 5:461-476.

CONCHA, M., VILlAR, M.E., TAFUR-SALGADO, R., IBANEZ, S. \& AZEVEDO, L., 2016. Fatherhood education from a cultural perspective: Evolving roles and identities after a fatherhood intervention for Latinos in South Florida. Journal of Latinos and Education, 15(3):170-179.

COTTEE, G. \& ROMAN, N.V. 2014. Perceptions of parental practices which place children at-risk for abuse and neglect. Child Abuse Research in South Africa, 15(2):26-34.

CRESWELL, J.W. 2014. Research design: Qualitative, quantitative and mixed research methods approaches. 4th ed. London: Sage.

DATCHI, C.C. 2017. Masculinities, fatherhood, and desistance from crime: Moderating and mediating processes involved in men's criminal conduct. The Journal of Men's Studies, 25(1):44-69.

DAVIS, M.T. 2014. Religious and non-religious components in substance abuse treatment: A comparative analysis of faith-based and secular interventions. Journal of Social Work, 14(3): 243-259.

ENDERSTEIN, A.M. \& BOONZAIER, F. 2015. Narratives of young South African fathers: Redefining masculinity through fatherhood. Journal of Gender Studies, 24(5):512-527.

FAGAN, J. \& IGLESIAS, A., 1999. Father involvement programme effects on fathers, father figures, and their Head Start children: A quasi-experimental study. Early Childhood Research Quarterly, 14(2):243-269.

FERREY, A.E., HUGHES, N.D., SIMKIN, S., LOCOCK, L., STEWART, A., KAPUR, N., GUNNELL, D. \& HAWTON, K. 2015. The impact of self-harm by young people on parents and families: A qualitative study. Journal of BMJ: 1-7.

FUNK, L.M. \& KOBAYASHI, K.M. 2014. From motivations to accounts: An interpretive analysis of "living apart together" relationships in mid- to later-life couples. Journal of Family Issues, 37(8):11011122.

FYLE-THORPE, O. 2017. The experiences of low-income non-resident African American fathers with parenting and depressive symptoms. Journal of Global Nursing e-Repository: 1-22. 
GOLDBERG, J.S. \& CARLSON, M.J. 2014. Parents' relationship quality and children's behaviour in stable married and cohabiting families. Journal of Marriage and Family, 76(4): 762-777.

GORDO, L., OLIVER-ROIG, A., MARTINEZ-AMPLIEGA, A., EEJAIDE, I., FERNANDEZALCANTARA, \& RICHART-MARTINEZ, Z. 2018. Parental perception of child vulnerability and parental competence: The role of postnatal depression and parental stress in fathers and mothers. Journal of Parental Perception of Child Vulnerability, 13(8):1-13.

GROVE, S.K., BURNS, N. \& GRAY, J.R. 2013.The practice of nursing research. Missouri: Elsevier. GREGORY, A. \& MILNER, S. 2011. What is "new" about fatherhood?: The social construction of fatherhood in France and the UK. Men and Masculinities, 14(5):588-606.

GRUNDETJERN, H., COPES, H. \& SANDBERG, S., 2019. Dealing with fatherhood: Paternal identities among men in the illegal drug economy. European Journal of Criminology: 1-17

HARTLEY, S.L. \& SELTZER, M. 2012. Psychological well-being in fathers of adolescents and young adults with down syndrome, fragile X syndrome, and autism. Journal of Family Relations, 61:327-342.

HENRY, J.B., JULION, W.A., BOUNDS, D.T. \& SUMO, J.N., 2020. Fatherhood matters: An integrative review of fatherhood intervention research. The Journal of School Nursing, 36(1): 19-32.

HERLAND, M.D., HAUGE, M. \& HELGELAND, I.M. 2015. Balancing fatherhood: Experiences of fatherhood among men with a difficult past. Journal of Qualitative Social Work, 14(2): 242-258.

KRALJEVIC, S., BANOZIC, A., MARIC, A., COSIC, A., SAPUNAR, D. \& PULJAK, L. 2011. Parents' pain catastrophizing is related to pain catastrophizing of their adult children. International Journal of Behavioral Medicine, 19(1):115-119

LAMB, M. E. 2010. The role of the father in child development. $5^{\text {th }}$ ed. Cambridge: University of Cambridge.

LASSER, J., FITE, K. \& WADENDE, A.P., 2011. Fatherhood in Kenyan ethnic communities: Implication for child development. School Psychology International, 32(1). 49-57.

LE, B.M., SAKALUK, J.K., DAY, I.C. \& IMPETT, E.A. 2018. How gender, age, and socioeconomic status predict parenting goal pursuit. Journal of Social and Personal Relationships, 36(10):3313-3338.

LE, B.M., SAKALUK, J.K., DAY, I.C. \& IMPETT, E.A. 2019. Parenting goal pursuit is linked to emotional wellbeing, relationship quality, and responsiveness. Journal of Social and Personal Relationships, 36(3): 879-904.

LEE, E.H., ZHOU, Q., EISENBERG, N., \& WANG, Y. 2012. Bidirectional relations between temperament and parenting styles in Chinese children. Journal of Behavioural Development, 37(1):5767.

MAGARAGGIA S. 2012. Gender in theory and practice: An interview with Raewyn Connell. Feminist Review, 102(1):116-124.

MAK, K., HO, S., THOMAS, G.N., SCHOOLING, C.M., McGHEE, S.M., \& LAM, T. 2010. Family structure, parent-child conversation time and substance use among Chinese adolescents. Journal of BMC Public Health, 10:503.

MAKUSHA, T., RICHTER, L., KNIGHT, L., VAN ROOYEN, H., \& BHANA, D. 2013. "The good and the bad?" Childhood experiences with fathers and their influence on women's expectations and men's experiences of fathering in rural KwaZulu-Natal, South Africa. Fathering: A Journal of Theory, Research, and Practice about Men as Fathers, 11(2): 138-158.

MAXWELl, N., SCOURFIELD, J., FEATHERSTONE, B., HOLLAND, S., \& TOLMAN, R. 2012. Engaging fathers in child welfare services: A narrative review of recent research evidence. Child \& Family Social Work 17(2): 160-169. 
MCKINNEY, C., MORSE, M., \& PASTUSZAK, J. 2017. Effective and ineffective parenting: Associations with psychological adjustment in emerging adults. Journal of Family Issues, 37(9):12031225.

MOKWENA, K. 2016. "Consider our Plight": A cry for help from Nyaope. Journal of Health SA Gesondheid, 21:137-142.

MOUNT, N. \& DILLON, G. 2014. Parents' experiences of adolescent diagnosed spectrum disorder. Journal of Education \& Child Psychology, 32(4):70-78.

NELSON, J.J. \& UECKER, J.E. 2078 Are religious parents more satisfied parents? Individual and couple-level religious correlates of parenting satisfaction. Journal of Family Issues, 39(7): 1770-1796.

PETRUZZI, L.J., PULLEN, S.S., LANGE, B.C.L., PARNAROUSKIS, L., DOMINGUEZ, S., HARRIS, B., QUITERIO, N., LEKPEH, G., MANOBAH, B., HENDERSON, D.C. \& BORBA, C.P.C. 2018. Contributing risk factors for substance use among youth in post conflict Liberia. Journal of Quality Health Research, 28(12):1827-1838.

PLECK, J.H. 2010. Fatherhood and masculinity. The Role of the Father in Child Development, 5:2757.

RANDLES J. 2018. Making men into "responsible" fathers. Contexts, 17(2):34-39.

RATELE, K., SHEFER, T. \& CLOWES, L., 2012. Talking South African fathers: A critical examination of men's constructions and experiences of fatherhood and fatherlessness. South African Journal of Psychology, 42(4):553-563.

REHEL, E.M. 2014. When dad stays home too: Paternity leave, gender, and parenting. Gender \& Society, 28(1):110-132.

RICHARDSON, J.B. \& VAN BRAKLE, M. 2011. A qualitative study of relationships among parenting strategies, social capital, the juvenile justice system, and mental health care for at-risk African American male youth. Journal of Correctional Health Care, 17(4):319-328.

RECZEK, C., LIU, H. \& UMBERSON, D. 2010. Just the two of us? How parents influence adult children's marital quality. Journal of Marriage and Family, 72(5):1205-1219.

SAMODIEN, L.2018. The Ellen Pakkies story: Getting to know the mother driven to kill her son. Daily Maverick, 13 September. [Online] Available: https://www.dailymaverick.co.za/opinionista/2018-09-13the-ellen-pakkies-story-getting-to-know-the-mother-driven-to-kill-her-son) [Accessed: 14 December 2020].

SHIRANI F, HENWOOD K, COLTART C. 2012. Meeting the challenges of intensive parenting culture: Gender, risk management and the moral parent. Sociology, 46(1):25-40.

SCHMIDT, E.M. 2018. Breadwinning as care? The meaning of paid work in mothers' and fathers' constructions of parenting. Community, Work \& Family, 21(4):445-462.

SCHMITZ, R.M., 2016. Constructing men as fathers: A content analysis of formulations of fatherhood in parenting magazines. The Journal of Men's Studies, 24(1):3-23.

SCHULTZ, P. \& ALPASLAN, A. H. 2016. Our brothers' keepers: Siblings abusing chemical substances living with non-using siblings. Social Work /Maatskaplike Werk, 52(1):90-111.

SHEIDOW, A.J., HENRY, D.B., TOLAN, P.H., \& STRACHAN, M.K. 2014. The role of stress exposure and family functioning in internalizing outcomes of urban families. Journal of Child Family Studies, 23(8):1351-1365.

SKROBANEK, J \& KUGLSTATTER, V. 2019. Lifestyle and substance use among adolescents: A Bourdieusian perspective. Young, 27(2):140-163. 
SMITH, J.M. \& ESTEFAN, A. 2014. Families parenting adolescents with substance abuse - Recovering the mother's voice: A narrative literature review. Journal of Family Nursing, 20(4):415-441.

STAHLSCHMIDT, M.J., THRELFALL J., SEAY, K.D., LEWIS, E.M., \& KOHL, P.L. 2014. Recruiting fathers to parenting programs: Advice from dads and fatherhood programme providers. Journal of National Institute of Health, 35(10):1734-1741.

STEARNS, D.C. \& PARROTT, W.G. 2012. When feeling bad makes you look good: Guilt, shame, and person perceptions. Journal of Cognition and Emotion, 26(3):407-430.

THARP, A.T. \& NOONAN, R.K. 2012. Associations between three characteristics of parent-youth relationships, youth substance use, and dating attitudes. Journal of Health Promotion Practice, 13(4):515-523.

TERRETT, G., WHITE, R. \& SPRECKLEY, M. 2012. A preliminary evaluation of the parent-child mother Goose programme in relation to children's language and parenting stress. Journal of Early Childhood Research, 11(1):16-26.

TORRES, M., SNG, R. \& DEANE, F. P. 2015. Establishing a parenting programme for fathers in substance abuse treatment. Journal of Family Therapy, 36:273-288.

VETELÄINEN, A., GRÖNHOLM, H. AND HOLMA, J. 2013. 'Discussions of fatherhood in male batterer treatment group'. SAGE Open.

VON GREIFF, N. \& SKOGENS, L. 2017. Positive processes of change among male and female clients treated for alcohol and/or drug problems. Journal of Social Work, 17(2):186-206

VOISIN, D.R., KIM, D.H., BASSETT, S. \& MAROTTA, P.L. 2018. Pathways linking family stress to youth delinquency and substance use: Exploring the mediating roles of self-efficacy and future orientation. Journal of Health Psychology, 25(2): 139-151.

YOON, S., BELLAMY, J.L., KIM, W. \& YOON, D., 2018. Father involvement and behaviour problems among preadolescents at risk of maltreatment. Journal of Child and Family Studies, 27(2):494-504.

ZAHN, R., LYTHE, K.E., GETHIN, J.A., GREEN, S., WILLIAM, J.F., YOUNG, A.H. \& MOLL, J. 2015. The role of self-blame and worthlessness in the psychopathology of major depressive disorder. Journal of Affective Disorders, 186(1):1-13.

ZANONI, L., WARBURTON, W., BUSSEY, K., \& McMAUGH, A. 2014. Are all fathers in child protection families uncommitted, uninvolved and unable to change? Journal of Children and Youth Services Review, 41:83-94.

ZEMP, M., MILEK, A., CUMMINGS, E.M., CINA, A. \& BODENMANN, G., 2016. How couple-and parenting-focused programmes affect child behavioural problems: A randomized controlled trial. Journal of Child and Family Studies, 25(3):798-810. 